\title{
PENGETAHUAN DAN PENGGUNAAN PRODUK PEMUTIH DAN PENCERAH DI KECAMATAN SUKOLILO SURABAYA
}

\author{
Khintan Rizky Fadhila, Dwi Rekno Ningrum, Anisah Febrian Rahmawati, Athaya Bella Azzahrya, Dewi \\ Fatima Auzianingrum Muntari, Rini Ayu Agustin, Ayu Larasati, Dyandra Anjani Putri, Azza Maulidia El \\ Java, Siti Sarah, Andreas Bayu Eka Wijayanto, Rahmadi Wahyu Bowolaksono, Firman Wahyudi, Yunita \\ Nita* $^{*}$
}

Departemen Farmasi Komunitas, Fakultas Farmasi, Universitas Airlangga Gedung Nanizar Zaman Joenoes Kampus C, Jl. Ir. Soekarno, Surabaya 60115, Indonesia

E-mail: yunitanita@ff.unair.ac.id

\begin{abstract}
ABSTRAK
Konsep cantik di masyarakat salah satunya memiliki kulit putih dengan cara menggunakan produk pemutih dan pencerah kulit. Namun terdapat sejumlah produk pemutih yang mengandung bahan berbahaya. Pemilihan produk pemutih harus diperhatikan dengan baik dan benar. Tujuan penelitian ini adalah untuk mengetahui pengetahuan dan penggunaan masyarakat mengenai produk pemutih dan pencerah, serta hubungan antara tingkat pendidikan dan pengetahuan masyarakat mengenai produk pemutih dan pencerah. Penelitian dilakukan pada bulan September 2019 menggunakan metode survei, rancangan studi cross sectional dengan teknik purposive random sampling. Responden dalam penelitian adalah wanita berusia 16-35 tahun $(\mathrm{n}=130)$. Dari hasil penelitian diperoleh bahwa produk pemutih dan pencerah yang paling banyak digunakan adalah produk komersil teregistrasi BPOM dengan persentase 69,2\% (92 responden). Tingkat pendidikan pengguna produk pemutih dan pencerah tertinggi adalah tingkat sarjana dan pascasarjana yaitu dengan persentase 64,6\% (84 responden). Rata-rata skor yang didapatkan dari 130 responden adalah 3,8. Sebanyak 87 responden (67\%) memiliki skor di bawah 4,6 yang dikategorikan memiliki pengetahuan rendah mengenai produk pemutih dan pencerah. Uji korelasi Spearman menujukkan terdapat hubungan antara tingkat pendidikan dengan pengetahuan responden mengenai produk pemutih dan pencerah $(\mathrm{p}=0,016)$. Responden dalam penelitian memiliki tingkat pengetahuan rendah mengenai produk pemutih dan pencerah serta terdapat hubungan antara tingkat pendidikan dengan pengetahuan tentang produk pemutih dan pencerah.
\end{abstract}

Kata Kunci: pemutih, pencerah, penggunaan, pengetahuan, pendidikan

\begin{abstract}
Society's beautiful concept is having white skin by using whitening and brightening products. There are numbers of whitening products that contain harmful ingredients. Therefore, whitening products must be selected properly. This study was aimed to determine the use and the knowledge about whitening and brightening products. The relationship between the level of education and their knowledge about whitening and brightening products in society. The study was conducted in September 2019 using a cross sectional survey with purposive sampling technique. Respondents were women aged 16-35 years $(\mathrm{n}=$ 130). The results showed that the most used whitening and brightening products were registered commercial products with a percentage of $69.2 \%$ (92 respondents). The highest educational level of the whitening and brightening products users is the undergraduate and postgraduate level, namely 84 respondents $(64.6 \%)$. The average score obtained from 130 respondents was 3.8. 87 respondents $(67 \%)$ had a score below 4.6, which was categorized as having low knowledge about whitening and brightening products. Spearman corrrelation test showed that there was a relationship between the educational level and the respondents' knowledge about whitening and brightening products $(p=0.016)$. Respondents have a low level of knowledge about whitening and brightening products and there is a relationship between the level of education with knowledge about whitening and brightening products.
\end{abstract}

Keywords: whitening, lightening, usage, knowledge, education 


\section{PENDAHULUAN}

Indonesia merupakan negara yang mayoritas masyarakatnya memiliki kulit berjenis sawo matang. Sedangkan, salah satu konsep kecantikan yang saat ini beredar di masyarakat adalah dengan memiliki kulit putih. Konsep kecantikan sebagaimana yang direkonstruksi oleh media massa yakni perempuan dengan indikator tubuh langsing dan tinggi, berkulit putih, paras manis, dan berambut panjang (Goenawan, 2007). Stigma ini menjadikan masyarakat khususnya para remaja untuk melakukan berbagai cara agar memiliki kulit putih. Salah satu cara untuk mempercantik kulit tersebut adalah dengan menggunakan produk pemutih dan pencerah kulit. Sebuah survei menyatakan bahwa wanita pada umur antara 17-22 tahun yang memakai krim pemutih sebanyak 35 orang (35\%), 25-35 tahun sebanyak 50 orang $(50 \%)$ dari jumlah seluruh responden penelitian sebanyak 100 orang (Dewi dan Salim, 2000).

Produk pemutih kulit telah banyak digunakan secara luas pada bidang kosmetik maupun terapi klinik. Produk tersebut digunakan untuk mencerahkan kulit (seseorang yang mengharapkan mengubah atau memodifikasi warna kulit) atau depigmentasi kulit (pengobatan hiperpigmentasi kulit yang abnormal seperti melasma, bintik-bintik, dan senile lentigines) (Zhai dan Maibach, 2009). Menurut Badan Pengawas Obat dan Makanan (BPOM) Republik Indonesia, terdapat sejumlah produk pemutih yang mengandung bahan berbahaya seperti merkuri dan hidrokuinon di luar izin BPOM. Selama tahun 2018, BPOM menemukan 112 miliar rupiah kosmetik ilegal dan/atau mengandung bahan dilarang/bahan berbahaya. Kosmetik ilegal yang ditemukan tersebut didominasi oleh produk kosmetik yang mengandung merkuri, hidrokuinon, dan asam retinoat (BPOM, 2018). Mekuri, hidrokuinon, dan kortikosteroid dilaporkan menjadi bahan aktif utama dalam produk pemutih kulit yang digunakan di Afrika (Olumide et al. 2008). Saat ini banyak krim pemutih yang mengandung merkuri (dari tiga sampel yang diteliti, satu diantaranya positif mengandung merkuri) (Trisnawati, 2017). Penelitian lain yang dilakukan oleh Weldon pada tahun 2000 terhadap pengguna krim kecantikan di Meksiko yang mengandung merkuri klorida menunjukkan pengguna krim melaporkan prevalensi yang tinggi mengenai gejala yang terkait dengan keracunan merkuri (Weldon et al. 2000).
Hidrokuinon digunakan sebagai campuran dalam krim pemutih karena senyawa ini mampu mengelupas kulit bagian luar dan menghambat pembentukan melanin. BPOM menyebutkan bahwa hidrokuinon hanya boleh digunakan untuk bahan pengoksidasi warna pada rambut dan kuku artifisial (BPOM, 2008). Bahan berbahaya lain yang sering ditambahkan dalam produk pemutih dan pencerah adalah steroid. Steroid ditambahkan dalam krim pemutih karena dapat menekan sintesis melanin tanpa menghancurkan melanosit (Febrina, 2019). Kasus munculnya efek samping karena penggunaan krim pemutih terjadi di Rumah Sakit Hasan Sadikin Bandung dengan ditemukanya rambut berlebihan serta bercak kemerahan tanpa adanya rasa gatal yang mana gejala tersebut menunjukkan efek samping dari pemakaian steroid jangka panjang (Febrina, 2019).

Pemilihan produk pemutih harus diperhatikan dengan baik dan benar mengingat produk akan digunakan dalam jangka waktu yang lama. Tujuan dari studi ini adalah untuk mengetahui pengetahuan dan penggunaan masyarakat terhadap penggunaan produk pemutih dan pencerah serta untuk mengetahui hubungan antara pendidikan dengan pengetahuan produk pemutih dan pencerah yang digunakan di masyarakat.

\section{METODE PENELITIAN}

Penelitian menggunakan cross sectional. Pengambilan data menggunakan kuesioner. Survei dilaksanakan di Kecamatan Sukolilo Surabaya. Teknik sampling yang digunakan adalah non-random sampling dengan teknik purposive sampling.

Instrumen yang digunakan untuk pengambilan data adalah kuesioner. Prosedur pengambilan sampel yang dilakukan dengan mendatangi salah satu Universitas, SMA/SMU, dan TK/PAUD di Kecamatan Sukolilo Surabaya, kemudian memberikan kuesioner kepada responden yaitu mahasiswi, siswi SMA/SMU, dan ibu wali murid TK/PAUD yang memenuhi kriteria inklusi.

Jumlah responden dalam studi ini adalah 130 responden. Kriteria inklusi responden adalah wanita dengan usia 15-35 tahun, sedang/pernah menggunakan produk pemutih dan pencerah, dan bersedia menjadi responden penelitian dibuktikan dengan menyetujui lembar inform consent. Terdapat tiga variabel yang diteliti yaitu (1) Karakteristik responden, (2) Penggunaan produk pemutih dan pencerah, dan 
(3) Pengetahuan mengenai produk pemutih dan pencerah yang ditunjukkan pada tabel 1 .

Tabel 1. Variabel Kuesioner

\begin{tabular}{ll}
\hline \hline Variabel & Indikator \\
\hline Karakteristik & Usia \\
\cline { 2 - 2 } Responden & Pendidikan terakhir \\
\cline { 2 - 2 } & Pekerjaan \\
\cline { 2 - 2 } & Produk pemutih dan pencerah \\
& yang digunakan \\
& $\begin{array}{l}\text { Lama penggunaan produk pemutih } \\
\text { dan pencerah }\end{array}$ \\
\cline { 2 - 2 } & $\begin{array}{l}\text { Alasan penggunaan produk } \\
\text { pemutih dan pencerah }\end{array}$ \\
\cline { 2 - 2 } & $\begin{array}{l}\text { Efek samping penggunaan produk } \\
\text { pemutih dan pencerah }\end{array}$ \\
\hline Pengetahuan & $\begin{array}{l}\text { Kandungan produk pemutih dan } \\
\text { pencerah yang aman }\end{array}$ \\
\cline { 2 - 2 } & $\begin{array}{l}\text { Produk pemutih dan pencerah } \\
\text { dengan bahan berbahaya }\end{array}$ \\
\hline \hline
\end{tabular}

Variabel dependen yang diteliti adalah pengetahuan dan penggunaan produk pemutih dan pencerah. Variabel independen yang diteliti adalah umur, pendidikan terakhir, dan pekerjaan. Penelitian ini untuk mengetahui hubungan variabel independen yaitu pendidikan terakhir dengan variabel dependen yaitu pengetahuan dan penggunaan mengenai produk pemutih dan pencerah. Dilakukan uji validitas kuesioner sebelum kuesioner digunakan. Data yang diperoleh melalui kuesioner dianalisis menggunakan uji Spearman. Dilakukan pengategorian tingkat pendidikan dan skoring pengetahuan. Skor tingkat pengetahuan responden dikategorikan menjadi dua tingkat yaitu pengetahuan rendah dengan skor 0-4,5 dan pengetahuan tinggi dengan skor 4,6-9 sesuai pada tabel 2 .

Tabel 2. Tabel Kategori Skor Pengetahuan Tentang Produk Pemutih dan Pencerah

\begin{tabular}{clc}
\hline \hline $\begin{array}{c}\text { Rentang } \\
\text { Skor }\end{array}$ & \multicolumn{1}{c}{$\begin{array}{c}\text { Kategori } \\
\text { Pengetahuan }\end{array}$} & $\mathrm{n}(\%)$ \\
\hline $0-4,5$ & Rendah & $87(67 \%)$ \\
\hline $4,6-9$ & Tinggi & $43(33 \%)$ \\
\hline \hline
\end{tabular}

\section{HASIL DAN PEMBAHASAN}

Tabel 3 menunjukkan karakteristik responden yang terpilih pada penelitian ini. Pengguna produk pemutih dan pencerah terbanyak berusia 16-20 tahun sebanyak 70 responden (53,8\%). Hasil penelitian di Pontianak pada tahun 2016 menunjukkan dari 34 subjek yang diteliti terdapat 15 subjek $(44,2 \%)$ berusia 21 tahun (Rini, 2016). Penelitian di Kabupaten Bone pada tahun 2016 dengan 100 responden menyebutkan bahwa pengguna krim pemutih terbanyak pada usia 2535 tahun yaitu 50 responden $(50 \%)$ (Dewi dan Salim, 2000). Sebagian besar responden pengguna produk pemutih dan pencerah adalah mahasiswi yang berpendidikan S1/S2/S3 sebayak 84 responden (64,6\%). Pengguna produk pemutih dan pencerah terbanyak berstatus sebagai mahasiswa yaitu 87 responden $(66,9 \%)$. Tingkat pendidikan tidak menentukan pemilihan krim pemutih tetapi status pekerjaan seseorang menentukan pemilihan produk krim pemutih kulit (Sari dan Siti, 2016).

Tabel 3. Profil Demografi Responden Pengguna Produk Pemutih dan Pencerah

\begin{tabular}{cc}
\hline \multicolumn{1}{c}{ Variabel } & $\mathrm{n}(\%)$ \\
\hline Usia & \\
\hline 16-20 tahun & $70(53,8 \%)$ \\
\hline $21-25$ tahun & $46(35,4 \%)$ \\
\hline $26-30$ tahun & $6(4,6 \%)$ \\
\hline 31-35 tahun & $8(6,2 \%)$ \\
\hline Pendidikan Terakhir & \\
\hline SD/sederajat & $2(1,5 \%)$ \\
\hline SMP/sederajat & - \\
\hline SMA/sederajat & $7(5,4 \%)$ \\
\hline D1/D2/D3/D4 & $37(28,5 \%)$ \\
\hline S1/S2/S3 & $84(64,6 \%)$ \\
\hline Pekerjaan & $87(66,9 \%)$ \\
\hline Mahasiswa & $17(13,1 \%)$ \\
\hline Pelajar & $16(12,3 \%)$ \\
\hline Swasta & $5(3,8 \%)$ \\
\hline Ibu rumah tangga & $2(1,5 \%)$ \\
\hline Guru & $3(2,3 \%)$ \\
\hline Wiraswasta &
\end{tabular}

\section{Penggunaan Produk Pemutih dan Pencerah}

Profil penggunaan produk pemutih dan pencerah kulit ditunjukkan pada tabel 6. Data profil penggunaan diambil untuk mengetahui pengalaman responden dalam menggunakan produk pemutih dan pencerah kulit. Mayoritas responden telah menggunakan produk kosmetik legal yang ditandai dengan registrasi produk oleh BPOM (90,77\%; 118 responden). Media sosial dan lingkungan terdekat (keluarga, teman) memiliki peranan penting dalam promosi produk yang dibuktikan dengan banyaknya responden yang mengetahui produk pemutih dan pencerah melalui kedua hal tersebut $(32,1 \% ; 45$ responden dan $32,9 \% ; 46$ responden). BPOM juga menyarankan untuk membeli produk kosmetik pada pedagang resmi dan berlisensi dengan menghindari produk yang dijual di pinggir jalan (BPOM RI, 2018). Penelitian menunjukkan masih terdapat 24 responden $(17,9 \%)$ yang membeli produk di pasar dan toko online sehingga keamanan, stabilitas dan cara penyimpanan produk tidak terjamin. Hal ini mendukung perlunya edukasi 
mengenai pentingnya membeli produk pada tempat resmi.

Penggunaan krim pemutih untuk dapat memberikan efek memerlukan waktu \pm 8 minggu (Lee et al. 2010). Durasi pemakaian krim pemutih sebelum terjadi komplikasi bervariasi mulai dari 6-60 bulan (Olumide et al. 2008). Terdapat 37 responden $(28,5 \%)$ menggunakan produk pemutih dan pencerah selama 1-6 bulan. Tidak sedikit responden yang telah menggunakan krim selama lebih dari 2 tahun $(21,5 \%$; 26 responden). Hal ini pun masih dalam kategori aman dan seharusnya tidak menimbulkan efek samping (Olumide et al. 2008). Adapun efek samping yang muncul pada responden dapat diakibatkan oleh beberapa faktor seperti bahan yang digunakan dan kerentanan atau sensitivitas kulit (Ingber dan Shai, 2009).

\section{Pengetahuan Mengenai Produk Pemutih dan Pencerah}

Profil pengetahuan responden tentang produk pemutih dan pencerah ditunjukkan pada tabel 4. Sebanyak 68 responden $(52,3 \%)$ tidak mengetahui cara untuk memastikan keamanan produk yang digunakan. Kosmetik harus memiliki izin edar yang dikeluarkan oleh BPOM dan mendapatkan nomor registrasi yang dapat diperiksa melalui website resmi BPOM (BPOM, 2003).

Berdasarkan hasil penelitian, 67 responden (51,54\%) tidak mengetahui bahwa vitamin C adalah bahan diperbolehkan dalam produk pemutih dan pencerah. Vitamin $\mathrm{C}$ (asam askorbat) adalah antioksidan terkenal sebagai agen pencerah dalam bentuk oral dan topikal. Mekanisme kerjanya dalam pengobatan melasma adalah berinteraksi dengan ion tembaga di situs aktif tirosinase dan menghambat melanogenesis dengan bertindak sebagai agen pereduksi dalam berbagai langkah oksidatif dari pembentukan melanin (Serena dan Bruce, 2015). Pengunaan vitamin C dalam sediaan tidak diatur dan vitamin $\mathrm{C}$ ditemukan pada kosmetik dengan konsentrasi $4 \%$ hingga 20\% (Couteau dan Coiffard, 2016). Asam askorbat tidak memiliki efek yang berbahaya (Jutley et al. 2014).

Dari seluruh pertanyaan yang diajukan, 65 responden $(50 \%)$ mengetahui jika merkuri tidak boleh digunakan dalam produk pemutih dan pencerah tetapi 103 responden $(79,2 \%)$ tidak mengetahui bahwa steroid tidak boleh digunakan dalam produk pemutih dan pencerah. Merkuri dan steroid tidak termasuk dalam bahan yang diperbolehkan sebagai bahan kosmetik dalam Peraturan Kepala BPOM Nomor 18
Tahun 2015 Pasal 2. Hidrokuinon hanya boleh digunakan untuk bahan pengoksidasi warna pada pewarna rambut dengan kadar maksimum $0,3 \%$ dan untuk kuku artifisial dengan kadar maksimum 0,02\% (BPOM, 2008). Hanya 28 responden $(21,8 \%)$ yang mengetahui bahwa hidrokuinon tidak boleh digunakan dalam produk pemutih dan pencerah.

Tabel 4. Profil Pengetahuan Responden tentang Produk Pemutih dan Pencerah

\begin{tabular}{|c|c|}
\hline Pernyataan & $\begin{array}{c}\text { Jawaban } \\
\text { Benar }\end{array}$ \\
\hline $\begin{array}{l}\text { Cara mengecek keamanan produk } \\
\text { pemutih dan pencerah yang digunakan }\end{array}$ & $\begin{array}{c}62 \\
(47,7 \%)\end{array}$ \\
\hline $\begin{array}{l}\text { Vitamin } \mathrm{C} \text { adalah bahan yang tidak boleh } \\
\text { digunakan dalam produk pemutih dan } \\
\text { pencerah }\end{array}$ & $\begin{array}{c}63 \\
(48,5 \%)\end{array}$ \\
\hline $\begin{array}{l}\text { Merkuri adalah bahan kimia yang boleh } \\
\text { digunakan dalam produk pemutih dan } \\
\text { pencerah }\end{array}$ & $\begin{array}{c}76 \\
(58,5 \%)\end{array}$ \\
\hline $\begin{array}{l}\text { Steroid adalah bahan kimia yang } \\
\text { diperbolehkan dalam produk pemutih dan } \\
\text { pencerah }\end{array}$ & $\begin{array}{c}27 \\
(20,8 \%)\end{array}$ \\
\hline $\begin{array}{l}\text { Hidrokuinon adalah bahan kimia yang } \\
\text { boleh digunakan secara bebas untuk } \\
\text { bahan produk pemutih dan pencerah tanpa } \\
\text { pengawasan }\end{array}$ & $\begin{array}{c}28 \\
(21,5 \%)\end{array}$ \\
\hline $\begin{array}{l}\text { Produk pemutih dan pencerah yang baik } \\
\text { adalah yang mengandung hidrokuinon } \\
\text { lebih dari } 2 \%\end{array}$ & $\begin{array}{c}25 \\
(19,2 \%)\end{array}$ \\
\hline $\begin{array}{l}\text { Penggunaan steroid jangka panjang pada } \\
\text { produk pemutih dan pencerah dapat } \\
\text { menyebabkan tumbuh rambut berlebihan } \\
\text { pada wajah }\end{array}$ & $\begin{array}{c}21 \\
(16,2 \%)\end{array}$ \\
\hline $\begin{array}{l}\text { Jika kulit mulai memerah dan/atau gatal, } \\
\text { produk pemutih dan pencerah tetap bisa } \\
\text { digunakan }\end{array}$ & $\begin{array}{c}112 \\
(86,2 \%)\end{array}$ \\
\hline $\begin{array}{l}\text { Tidak terdapat efek berbahaya } \\
\text { penggunaan produk pemutih dan pencerah } \\
\text { mengandung merkuri pada ibu hamil dan } \\
\text { menyusui }\end{array}$ & $\begin{array}{c}83 \\
(63,8 \%)\end{array}$ \\
\hline
\end{tabular}

Sebanyak 102 responden (78,5\%) tidak mengetahui larangan penggunan hidrokuinon. Komplikasi penggunaan hidrokuinon yang telah dilaporkan yaitu dermatitis, katarak, pigmentasi kuku dan sklera, okronosis eksogenus, dan pigmentasi tidak merata (Olumide et al. 2008). Bahaya steroid juga belum diketahui oleh 109 responden (83,8\%). Komplikasi yang ditimbulkan dari penggunaan steroid topikal 
diantaranya yaitu atropi kulit, telangiektasis, hipopigmentasi, dan steroid addictive syndrome (Olumide et al. 2008). Penggunaan steroid jangka panjang juga menyebabkan pertumbuhan rambut yang berlebihan dan bercak kemarahan pada wajah (Febrina, 2019).

Pengetahuan responden bahwa merkuri adalah bahan berbahaya yang tidak boleh digunakan dalam produk- produk pemutih dan pencerah lebih tinggi daripada pengetahuan tentang hidrokuinon dan steroid. Hal ini dibuktikan dengan banyaknya responden yang menjawab benar pada kuesioner yaitu 76 responden $(58,46 \%)$. Merkuri memiliki efek samping skin atrophy, alergi dermatitis kontak, dan diskromia (Baran dan Pons-Guiraud, 2010). Sebanyak 83 responden $(63,8 \%)$ responden mengetahui bahwa terdapat efek berbahaya penggunaan produk pemutih dan pencerah yang mengandung merkuri pada ibu hamil dan menyusui. Merkuri dapat menembus plasenta dan dapat ditransfer melalui ASI sehingga dapat mempengaruhi perkembangan saraf dan ginjal pada janin dan bayi (Al Saleh, 2016).

Skor terendah dan tertinggi yang diperoleh responden beturut-turut adalah 0 dan 9 . Sebagian besar responden memiliki tingkat pengetahuan yang rendah mengenai produk pemutih dan pencerah yang dibuktikan dengan 87 responden (67\%) mendapatkan skor kurang dari 4,6.

\section{Hubungan Tingkat Pendidikan dengan Pengetahuan Mengenai Produk Pemutih dan Pencerah}

Penelitian ini juga bertujuan untuk melihat hubungan antara tingkat pendidikan dan pengetahuan responden terhadap produk pemutih dan pencerah dengan menggunakan uji korelasi Spearman. Setelah dilakukan uji korelasi Spearman, diperoleh nilai $\mathrm{p}=0,016$ yang mana nilai tersebut lebih tinggi dari $\alpha$ $(\mathrm{p}<0,05)$ maka dapat disimpulkan bahwa ada hubungan yang bermakna antara tingkat pendidikan dengan pengetahuan responden. Hasil analisis statistik hubungan tingkat pendidikan dan pengetahuan mengenai produk pemutih dan pencerah dapat dilihat pada tabel 5 .

Tabel 5. Hasil uji Spearman hubungan tingkat pendidikan dengan pengetahuan mengenai produk pemutih dan pencerah

\begin{tabular}{cccc}
\hline Variabel & $\begin{array}{c}\text { Koefisien } \\
\text { Korelasi }\end{array}$ & p Value & $\mathrm{N}$ \\
\hline $\begin{array}{c}\text { Tingkat } \\
\text { pendidikan } \\
\text { terhadap } \\
\text { pengetahuan }\end{array}$ & 0,211 & 0,016 & 130 \\
\hline \hline
\end{tabular}

Ket : aanalisis menggunakan uji Spearman

Uji tersebut juga dapat digunakan untuk mengetahui tingkat kekuatan hubungan melalui nilai $r$ (koefisien korelasi). Nilai $r$ yang diperoleh sebesar 0,211 yang menunjukkan bahwa hubungan antara tingkat pendidikan responden dengan pengetahuan tergolong sangat lemah. Nilai $r$ yang positif menunjukkan bahwa tingkat pendidikan berhubungan linier dengan pengetahuan. Artinya, semakin tinggi pendidikan seseorang, maka pengetahuan yang dimiliki juga semakin baik. Hal ini sesuai dengan penelitian yang dilakukan oleh Powell et al. (2007) bahwa seseorang dengan tingkat pendidikan rendah akan memiliki pengetahuan yang kurang mengenai manajemen penyakit DM tipe 2 (Powell et al. 2007). 
Tabel 6. Penggunaan produk pemutih dan pencerah

\begin{tabular}{|c|c|c|c|}
\hline Variabel & $\mathrm{n}(\%)$ & Variabel & $\mathrm{n}(\%)$ \\
\hline Produk* & & $\begin{array}{l}\text { Lama } \\
\text { Penggunaan }\end{array}$ & \\
\hline Komersil registrasi & $92(69,2 \%)$ & $<1$ bulan & $20(15,4 \%)$ \\
\hline Klinik registrasi & $29(21,8 \%)$ & $7-12$ bulan & $14(10,8 \%)$ \\
\hline Komersil tidak registrasi & $9(6,8 \%)$ & $1,5-2$ tahun & $14(10,8 \%)$ \\
\hline \multirow[t]{3}{*}{ Klinik tidak registrasi } & $3(2,3 \%)$ & 1-6 bulan & $37(28,5 \%)$ \\
\hline & & $1-1,5$ tahun & $17(13,1 \%)$ \\
\hline & & Lebih dari 2 tahun & $28(21,5 \%)$ \\
\hline $\begin{array}{l}\text { Informasi Produk Pemutih } \\
\text { dan Pencerah* }\end{array}$ & & Alasan Penggunaan* & \\
\hline Televisi & $38(27,1 \%)$ & Mencerahkan kulit & $89(67,4 \%)$ \\
\hline $\begin{array}{l}\text { Keluarga/kerabat/ } \\
\text { teman }\end{array}$ & $46(32,9 \%)$ & Tuntutan pekerjaan & $1(0,8 \%)$ \\
\hline Buku & $1(0,7 \%)$ & $\begin{array}{l}\text { Mengikuti saran } \\
\text { dokter/teman/keluarga/ } \\
\text { beauty vlogger }\end{array}$ & $24(18,2 \%)$ \\
\hline Koran/surat kabar & $1(0,7 \%)$ & Lain-lain & $18(13,6 \%)$ \\
\hline Lain-lain & $5(3,6 \%)$ & & \\
\hline Majalah & $4(2,9 \%)$ & & \\
\hline Media sosial & $45(32,1 \%)$ & & \\
\hline Tempat Pembelian* & & Efek samping yang pernah di & \\
\hline Apotek & $5(3,7 \%)$ & Tidak ada efek samping & $93(68,9 \%)$ \\
\hline Toko kosmetik & $68(50,7 \%)$ & Flek hitam & $6(4,4 \%)$ \\
\hline Agen distributor & $7(5,2 \%)$ & Iritasi (kemerahan) & $12(8,9 \%)$ \\
\hline Pasar & $9(6,7 \%)$ & Muncul jerawat & $13(9,6 \%)$ \\
\hline Toko online & $15(11,2 \%)$ & Lain-lain & $11(8,1 \%)$ \\
\hline Klinik kecantikan/dokter & $30(22,4 \%)$ & & \\
\hline
\end{tabular}

Ket :* Responden dapat menjawab lebih dari satu pilihan jawaban

\section{KESIMPULAN}

Dari penelitian tentang pengetahuan dan penggunaan produk pemutih dan pencerah di Kecamatan Sukolilo Surabaya pada bulan
September 2019 diperoleh kesimpulan bahwa, tingkat pengetahuan responden mengenai produk pemutih dan pencerah tergolong rendah dengan 87 responden $(67 \%)$ mendapatkan skor kurang dari 4,6. Tingkat pendidikan 
berpengaruh terhadap pengetahuan mengenai produk pemutih dan pencerah $(\mathrm{r}=0,0211 ; p$ value $=0,016)$.

\section{DAFTAR PUSTAKA}

Al-Saleh, I 2016, 'Potential health consequences of applying mercurycontaining skin lightening creams during pregnancy and lactation periods', International Journal of Hygiene and Environmental Health, 219 (4-5), p. 468474.

Baran, R, Pons-Guiraud, A 2010, Cosmetics for Men. In Textbook of Cosmetic Dermatologyfourth edition, Informa Healthcare, London.

BPOM RI 2003, Keputusan Kepala Badan Pengawas Obat dan Makanan (BPOM) Republik Indonesia Nomor: HK.00.05.4.1745 Tentang Kosmetik, BPOM RI, Jakarta.

BPOM RI 2008, Peraturan Kepala Badan Pengawas Obat dan Makanan (BPOM) Republik Indonesia Nomor: HK.00.05.42.1018 Tentang Bahan Kosmetik, BPOM RI, Jakarta.

BPOM RI 2015, Peraturan Kepala Badan Pengawas Obat dan Makanan (BPOM) Republik Indonesia tentang Persyaratan Teknis Bahan Kosmetika, BPOM RI, Jakarta.

BPOM RI 2018, Public Warning No. BHM.01.01.1.44.11.18.5410. Tentang Kosmetika Mengandung Bahan Berbahaya. 14 November 2018, BPOM RI, Jakarta

Couteau, C, Coiffard, L 2016, 'Overview of skin whitening agents: drugs and cosmetic products', Cosmetics, 3(3), 27.

Dewi, R, Salim, H 2000, 'Tingkat Pengetahuan Masyarakat Terhadap Bahaya Penggunaan Krim Pemutih di Lingkungan Desa Polewali Kecamatan Tellu Limpoe Kabupaten Bone. Media', Jurusan Farmasi Poltekkes Kemenkes Makassar, 3(1), pp. 1-29.

Febrina, D, Hindritiani, R, Ruchiatan, K 2019, 'Efek samping kortikosteroid topikal jangka lama pada wajah. syifa', MEDIKA: Jurnal Kedokteran dan Kesehatan, 8(2), pp.68-76.
Goenawan, F 2007, 'Ekonomi politik iklan di indonesia terhadap konsep kecantikan'. Jurnal Ilmiah Scriptura, 1(1): 14-24.

Ingber, A, Shai, A 2009, Inflammation, Dermatitis, and Cosmetics, In Handbook of Cosmetic Skin Care $2^{\text {nd }} e d$. Informa Healthcare, London.

Jutley, GS, Rajaratnam, R, Halpern, J, Salim, A, \& Emmett, C 2014, 'Systematic review of randomized controlled trials on interventions for melasma: an abridged cochrane review', Journal of the American Academy of Dermatology, 70(2), 369-373.

Lee, J, Jun, H, Jung, E, Ha, J, Park, D 2010, 'Whitening effect of $\alpha$-bisabolol in asian women subjects', International Journal of Cosmetic Science, 32, pp. 299-303.

Olumide, YM, Akinkugbe, AO, Altraide, D, Mohammed, T, Ahamefule, N, Ayanlowo, S, Onyekonwu, C, Essen, N 2008, 'Complications of chronic use of skin lightening cosmetics', International Journal of Dermatology, 47(4), pp. 344-353.

Powell, CK, Hill, EG, Clancy, DE 2007, 'The relationship between health literacy and diabetes knowledge and readiness to take health actions', Diabetes Educator, 33(1), pp. 144-151.

Rini, TA 2016, 'Hubungan antara penggunaan krim pemutih wajah dengan terjadinya telangiektasis pada para model sanggar insix di Pontianak', Jurnal Mahasiswa PSPD FK Universitas Tanjungpura, 3(1), pp. 1-15.

Sari, RNA, Siti ATSE 2016, 'Hubungan tingkat pendidikan dan status pekerjaan terhadap pemilihan kosmetik pencerah kulit pada wanita', Mutiara Medika: Junal Kedokteteran dan Kesehan, 12(3), pp. 170176.

Serena, NB, Bruce Smoller, G 2015, 'An overview on melasma', Journal of Pigmentary Disorders, 2(10), pp. 1-18.

Trisnawati, FA, Yulianti, CH, Ebtavanny, TG 2017, 'Identifikasi kandungan merkuri pada beberapa krim pemutih yang beredar di pasaran (studi dilakukan di pasar DTC Wonokromo Surabaya)' Journal of Pharmacy and Science, 2(2), 35-40. 